\title{
Soil chemical management drives structural degradation of Oxisols under a no-till cropping system
}

\author{
Márcio R. Nunes ${ }^{\mathrm{A}, \mathrm{H}}$, Alvaro P. da Silva ${ }^{\mathrm{G}}$, José E. Denardin ${ }^{\mathrm{B}}$, Neyde F. B. Giarola ${ }^{\mathrm{C}}$, \\ Carlos M. P. Vaz ${ }^{\mathrm{D}}$, Harold M. van Es ${ }^{\mathrm{E}}$, and Anderson R. da Silva ${ }^{\mathrm{F}}$ \\ AUniversity of São Paulo/Luiz de Queiroz College of Agriculture, Department of Soil Science, \\ Pádua Dias, 11, CEP 13418-900 - Piracicaba, São Paulo, Brazil. \\ ${ }^{B}$ Embrapa Trigo, Rodovia BR 285, km 294, CEP 99001-970 - Passo Fundo, Rio Grande do Sul, Brazil. \\ ${ }^{\mathrm{C}}$ State University of Ponta Grossa, Department of Soil Science and Agricultural Engineering, Gal. Carlos \\ Cavalcanti, CEP 84030-900 - Ponta Grossa, Paraná, Brazil. \\ DEmbrapa Agricultural Instrumentation, CEP 13560-970 - São Carlos, São Paulo, Brazil. \\ ${ }^{\mathrm{E} C o r n e l l}$ University, School of Integrative Plant Science, Soil and Crop Sciences Section, Ithaca, \\ NY 14853-1901, USA. \\ FFederal Institute Goiano, Department of Agronomy, Urutai, Goiás, Brazil. \\ ${ }^{\mathrm{G}}$ Deceased. Formerly of University of São Paulo/Luiz de Queiroz College of Agriculture, \\ Department of Soil Science, Pádua Dias, 11, CEP 13418-900 - Piracicaba, São Paulo, Brazil. \\ ${ }^{\mathrm{H}}$ Corresponding author. Email: marcio_r_nunes@usp.com; marcio_r_yahoo.com.br
}

\begin{abstract}
Physical degradation of the subsurface layer of soils reduces the effectiveness of no-till (NT) as a sustainable soil management approach in crop production. Chemical factors may reduce the structural stability of Oxisols and thereby exacerbate compaction from machinery traffic. We studied the relationship between chemical management and structural degradation in Oxisols cultivated under NT at three sites in southern Brazil. The surface and subsurface layers of the soils were characterised chemically and mineralogically and three physical attributes related to soil structural stability (readily dispersible clay in water, mechanically dispersible clay in water, and water percolation) were quantified for each layer. The same characterisations were performed on Oxisols collected from adjacent non-cultivated areas, to provide reference data for non-degraded soil. The levels of dispersed clay in the cultivated soil from the surface layer matched those of the noncultivated soil, but for the subsurface layer higher dispersed clay levels in the cultivated soil showed that it was physically degraded relative to the non-cultivated soil. Water percolation was found to be slower through the Oxisols cultivated under NT, irrespective of the soil layer. The relationships between the three indicators of soil structural stability and the measured chemical and mineralogical variables of the soils were explored through an analysis of canonical correlation. The principal variables associated with the lower stability of the cultivated vs non-cultivated Oxisols were the lower concentrations of organic carbon and exchangeable aluminium and, for the surface layer, the higher $\mathrm{pH}$. It is argued that structural degradation of Oxisols cultivated under NT, observed predominantly in the subsurface layer, has been aggravated by the accumulation of amendments and fertilisers in the surface soil and reduced levels of organic matter, especially in the subsurface layer.
\end{abstract}

Additional keywords: aggregate stability, clay dispersion, organic carbon, soil conservation.

Received 22 February 2017, accepted 2 June 2017, published online 28 June 2017

\section{Introduction}

The no-till (NT, direct drilling) system has been adopted in more than 150 million ha of agricultural soils in the world, and more than 30 million ha in Brazil (FAO 2016). When a NT system of agriculture is adopted, the soil is only disturbed along the seeding lines, with plant and crop residues remaining on the surface of the soil. This reduction in the intensity of disturbance brings economic and environmental benefits (Babujia et al. 2010; Derpsch et al. 2014; Corbeels et al. 2016). However, observations of soil cultivated under NT has revealed the formation of a layer, between $\sim 0.07$ and $0.20 \mathrm{~m}$ depth, of increased bulk density and resistance to penetration, with poor water and air permeability (Reichert et al. 2009; Soane et al. 2012; Dang et al. 2015; Nunes et al. 2015a). The existence of this layer promotes soil erosion by water (Denardin et al. 2011) and concentration of crop roots near the surface of the soil (Nunes et al. 2015b), which reduces the availability of water and nutrients to the plants (Reichert et al. 2009). This physical 
soil degradation therefore acts to reduce the positive effects expected from the adoption of NT.

Machinery traffic is normally cited as the principal cause of compaction in agricultural soils (Reichert et al. 2009; Soane et al. 2012). However, in addition to these mechanical processes, chemical factors can also contribute to structural degradation of soils managed under NT. This could be associated with the recurrent applications of limestone and fertilisers onto the surface of the soil, without incorporation. These products are known to promote physicochemical alterations within the soil (Haynes and Naidu 1998; Li and Zhang 2007), which can result in decreased aggregate stability and increased dispersion of clay (Roth and Pavan 1991; Castro and Logan 1991). The damage may principally occur close to the surface layer of soil, where the applied limestone and fertilisers accumulate (Costa and Rosolem 2007; Nunes et al. 2014).

For deeply weathered soils, such as the Oxisols of Brazil, the structural degradation stimulated by their chemical management can be especially pronounced because the natural $\mathrm{pH}$ of these soils is below the point of zero charge (PZC) for the majority of their minerals (Sposito 2008). In Oxisols, the formation of aggregation occurs at low $\mathrm{pH}$ and when there are high concentrations of $\mathrm{Al}^{3+}$ and diversified organic matter. Under these conditions, two types of linkages confer stability on the aggregates: electronegative functional groups of the organic matter bind to the electropositive domains of the oxides, and $\mathrm{Al}^{3+}$ ions form bridges between oxide domains (Vrdoljak and Sposito 2002; Six et al. 2002). However, liming raises the soil $\mathrm{pH}$, which leads to deprotonation of the surfaces of the oxides and kaolinite minerals, resulting in negative charges on soil particles and causing repulsion between them (Fontes et al. 1995). High concentrations of mono and bivalent salts are able to remove $\mathrm{Al}^{3+}$ from negatively charged sites within the soil. The subsequent occupation of these sites by lower valence cations and greater hydrated radius of cations weakens the intermolecular forces to destabilise the structure of the soil.

The NT system, under a high biomass production, have a high potential to increase organic carbon storage in Oxisols from subtropical (Madari et al. 2005) and tropical regions (Corbeels et al. 2016; Miranda et al. 2016), even being efficient in controlling soil organic matter degradation processes and in partially mitigating climate change (Siqueira Neto et al. 2010). However, in some of NT farming systems stablished in Brazil, the production model is based on monocultures or simple rotations, in which less quantities of organic matter are delivered to the soil. The uninterrupted adoption of NT in these production systems may be rendered impossible by the attendant lack of diversified organic matter inputs for the maintenance of soil stability (Conceição et al. 2013; Tivet et al. 2013; Derpsch et al. 2014). Therefore, the insufficient supply of organic material to the soil can be a factor contributing to the degradation of structure of these soils.

Unlike non-cultivated Oxisols, which have a naturally stable structure, previous studies have indicated that in the areas under NT, the clay dispersed in water by soil cultivation practices can be charged by percolating water, contributing to the obstruction of the natural porosity of the subsurface layers (Haridasan and Chibber 1971; Spera et al. 2008). Furthermore, in the surface layer of the soil, the lower stability and fragmentation of the macroaggregates can elevate the concentration of dispersible clay, leaving the system increasingly susceptible to erosion by water (Hudson 1977).

The majority of studies on fertilisation have evaluated the responses of plants to the application of fertilisers. Until now, few studies have been conducted to evaluate the effects of liming and mineral fertilisers on the structure of tropical and subtropical soils. There are, however, indications that chemical management of these soils can affect their mechanical properties (Chaplain et al. 2011), the stability of the aggregates, and the dispersion of clay (Castro and Logan 1991; Roth and Pavan 1991; Spera et al. 2008), potentially increasing the susceptibility of the soil to erosion by water (Castro and Logan 1991).

Hypothetically, both soil chemical management and low supply of organic material to the soil are contributing to promote Oxisol structural degradation under NT, which can result in decreased aggregate stability and increased clay dispersion. Thus, the objective of this study was to understand the relationship between chemical management and structural degradation for Oxisols cultivated under NT.

\section{Material and methods}

\section{Study areas}

Three locations with Oxisols were selected: two in the state of Rio Grande do Sul (RS) and one in the state of Paraná (PR; Fig. 1). At location LV-BR in Bom Recreio, RS ( $\left.28^{\circ} 7^{\prime} 12^{\prime \prime} \mathrm{S}, 52^{\circ} 28^{\prime} 9^{\prime \prime} \mathrm{W}\right)$, the soil was a Haplorthox (USDA 2012) or known as 'Latossolo Vermelho Distrófico' as per the Brazilian system soil classification (Santos et al. 2006), cultivated under NT for 12 years. The cropping system comprised soybean (Glycine max L.) and maize (Zea mays L.) in the summer season (November-May) and the land is left fallow in the winter (May-November). The last liming $\left(5 \mathrm{Mg} \mathrm{ha}^{-1}\right)$ was performed 5 years before soil sampling. At LV-PF in Passo Fundo, RS ( $\left.28^{\circ} 22^{\prime} 51^{\prime \prime} \mathrm{S}, 52^{\circ} 18^{\prime} 47^{\prime \prime} \mathrm{W}\right)$, the soil is a Rhodic Hapludox (USDA 2012) or known as 'Latossolo Vermelho Distroférrico' according to the Brazilian system soil

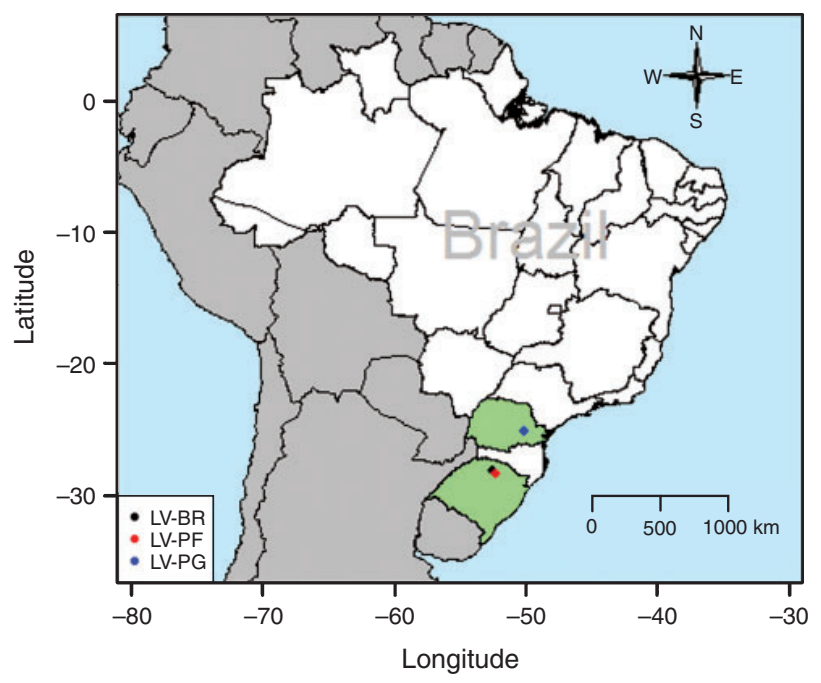

Fig. 1. Location of the experimental sites: LV-BR in Bom Recreio, RS (Haplorthox); LV-PF in Passo Fundo, RS, (Hapludox); LV-PG in Ponta Grossa, PR (Acrorthox). 
classification (Santos et al. 2006), cultivated under NT for 15 years. Here, soybean and maize were cultivated during the summer season; in the winter season, wheat (Triticum aestivum L.) was cultivated or the land was left fallow. The last liming ( $3 \mathrm{Mg}$ $\mathrm{ha}^{-1}$ ), was performed 3 years before sample collection. The third site, LV-PG, with an Acrorthox (USDA 2012) or known as 'Latossolo Vermelho Distrófico' according to the Brazilian system soil classification (Santos et al. 2006), was located in Ponta Grossa, PR $\left(25^{\circ} 10^{\prime} 0^{\prime \prime} \mathrm{S}, 50^{\circ} 9^{\prime} 57^{\prime \prime} \mathrm{W}\right)$ and had been cultivated under NT for 15 years. The crop rotation was soybean and maize, with green manure species (e.g. Crotalaria breviflora, Crotalaria juncea, Cajanus cajan, Mucuna deeringiana, and Pennisetum glaucum) in the summer, and wheat, black oats, (Avena strigosa L.), rye (Secale cereale L.) and vetch (Vicia sativa L.) in the winter. Liming $\left(3.5 \mathrm{Mg} \mathrm{ha}^{-1}\right)$ was last performed 4 years before sample collection.

The areas selected for the study are used for the commercial production of grains. They are representative of the production models and NT soil management systems practiced by the farmers of the respective regions. Fertilisation of crops involved the application of mineral fertilisers either along the seeding lines or over the surface. The mineral fertilisers used were previously formulated and contained nitrogen $(\mathrm{N})$, phosphorus as $\mathrm{P}_{2} \mathrm{O}_{5}$ and potassium as $\mathrm{K}_{2} \mathrm{O}$. Liming was performed exclusively by surface application, without incorporation into the soil. In the state of Rio Grande do Sul, calculations of fertilisation and liming requirements were based on analyses of soil collected from the 0-0.1 m layer, whereas in Paraná, the depth range considered was $0-0.20 \mathrm{~m}$. In the three study locations, the crop residues are left on the field.

For each cultivated area, an adjacent reference area with the similar soil (same soil classification, similar relief, and similar texture) was identified. These were under native vegetation (native vegetation from the 'Mata Atlântica' biome, comprising large, medium and small trees), and had not been under cultivation or received any chemical treatments (fertilisers, pesticides and liming) for at least 60 years. The reference area (non-cultivated area) was distant at $\sim 30-50 \mathrm{~m}$ from the cultivated areas under NT.

The climate for the two collection sites in RS, LV-BR and LV-PF, is humid subtropical (Cfa; Köppen classification), with average annual precipitation from 1300 to $1800 \mathrm{~mm}$ distributed throughout the year, with the greatest rainfall occurring during the months of May and June. Site LV-PG is within a region where the climate is predominantly humid subtropical mesothermal (Cfb). The mean annual precipitation is $1545 \mathrm{~mm}$, distributed throughout the year and the highest values occur in December, January and February. The seasons are less clearly defined in the $\mathrm{LV}-\mathrm{PF}$ region than in the RS and LV-BR regions.

\section{Soil sampling}

Soil samples were collected in December 2014, post-harvest to winter crops for sites LV-PF and LV-PG and before soybean sowing for LV-BR. Ten trenches, $0.30 \mathrm{~m}$ wide and $0.20 \mathrm{~m}$ deep, were opened at random points under NT cultivation at each site (trenches were located perpendicular the sowing lines). Inspection of the soil profile in the trenches led to the identification of two distinct soil layers. Layer 1 extended from the surface down to $\sim 0.07 \mathrm{~m}$, and was characterised by high porosity, visible to the naked eye, and an abundance of roots. Layer 2, located at depths between 0.07 and $0.20 \mathrm{~m}$, was denser, had a lower visible porosity, and contained fewer roots. The soil samples were collected from depths of 0 to $0.05 \mathrm{~m}$ (Layer 1) and 0.10 to $0.15 \mathrm{~m}$ (Layer 2). Soil samples were also collected from the same depths at 10 random points within the previously selected non-cultivated reference areas. Therefore, 120 soil samples were collected in total (3 Oxisols $\times 2$ layers $\times 2$ management types $\times 10$ points $=120$ samples). Both Layer 1 and Layer 2 were located within the A horizon. After collection, soil samples were sealed in plastic containers, so as to maintain moisture contents similar to field conditions (Table 1). This procedure was followed to avoid wetting and drying of the soil, processes which affect the stability of soil aggregates and clay dispersion (Dexter et al. 2011).

\section{Measurements}

\section{Physical, chemical and mineralogical properties}

Chemical assessments. Chemical assessments were as follows: $\mathrm{pH}$ in water (Donagema et al. 2011); calcium $\left(\mathrm{Ca}^{2+}\right)$, magnesium $\left(\mathrm{Mg}^{2+}\right)$, and potassium $\left(\mathrm{K}^{+}\right)$extracted with ammonium acetate and determined by atomic absorption spectrophotometry; potential acidity $\left(\mathrm{H}^{+}+\mathrm{Al}^{3+}\right)$ extracted with calcium acetate and determined by titration; aluminium $\left(\mathrm{Al}^{3+}\right)$ extracted with potassium chloride $(1 \mathrm{M})$ and determined by titration; and phosphorus using Melich-1 extraction and determined by colourimetry. From these, the base sum $\left(\mathrm{SB}=\mathrm{K}^{+}+\mathrm{Ca}^{2+}+\right.$ $\left.\mathrm{Mg}^{2+}\right)$ the cation exchange capacity $\left(\mathrm{CEC}=\mathrm{H}^{+}+\mathrm{Al}^{3+}+\mathrm{SB}\right)$, the base saturation of $\mathrm{CEC}(\% \mathrm{BS}=\mathrm{SB} / \mathrm{CEC})$, and saturation by aluminium $\left(\% \mathrm{Al}=\mathrm{Al}^{3+} /\left(\mathrm{SB}+\mathrm{Al}^{3+}\right)\right.$ were calculated. Organic carbon (OC) was determined by the Walkley-Black method (Donagema et al. 2011). Concentrations of the oxides of silicon $\left(\mathrm{SiO}_{2}\right)$, aluminium $\left(\mathrm{Al}_{2} \mathrm{O}_{3}\right)$, titanium $\left(\mathrm{TiO}_{2}\right)$, iron $\left(\mathrm{Fe}_{2} \mathrm{O}_{3}\right)$ and manganese $(\mathrm{MnO})$ were determined following extraction with a sodium dithionite-citrate-bicarbonate solution, according to Mehra and Jackson (1960).

Mineralogical measurements. The indices $K_{i}$ and $K_{r}$, defined as the molar ratios $\mathrm{SiO}_{2} / \mathrm{Al}_{2} \mathrm{O}_{3}$ and $\mathrm{SiO}_{2} /\left(\mathrm{Al}_{2} \mathrm{O}_{3}+\mathrm{Fe}_{2} \mathrm{O}_{5}\right)$ were

Table 1. Gravimetric water content of the soil samples at the moment of collection

\begin{tabular}{llcc}
\hline Soil & Soil use & Layer & $\begin{array}{c}\text { Moisture } \\
\left(\mathrm{kg} \mathrm{kg}^{-1}\right)\end{array}$ \\
\hline LV-BR $^{\mathrm{A}}$ & Cultivated under NT & 1 & 0.19 \\
& Not cultivated, under native vegetation & 1 & 0.20 \\
& $\quad$ (reference) & 2 & 0.18 \\
& Cultivated under NT & 1 & 0.17 \\
LV-PF $^{\mathrm{B}}$ & & 2 & 0.20 \\
& Not cultivated, under native vegetation & 1 & 0.16 \\
& $\quad$ (reference) & 2 & 0.16 \\
LV-PG & Cultivated under NT & 1 & 0.18 \\
& & 2 & 0.22 \\
& Not cultivated, under native vegetation & 1 & 0.22 \\
& $\quad$ (reference) & 2 & 0.22 \\
\hline
\end{tabular}

${ }^{\mathrm{A}}$ Haplorthox; ${ }^{\mathrm{B}}$ Hapludox; ${ }^{\mathrm{C}}$ Acrorthox. 
respectively calculated. A qualitative mineralogical analysis of the clay fraction of soil samples collected from $0-0.20 \mathrm{~m}$ in a non-cultivated area of each of the three sites was also performed. The clay fraction was isolated by processing the soil through the following steps: digestion of the organic matter with hydrogen peroxide, chemical dispersion with $10 \mathrm{~mL}$ of $0.1 \mathrm{M}$ sodium hydroxide, mechanical dispersion on a rotisserie-style tube rotator $(16 \mathrm{~h}$ at $25 \mathrm{rpm})$, followed by removal of the sand fraction by wet-sieving. The suspension of silt and clay in water was then transferred to a $1000-\mathrm{mL}$ graduated cylinder, where silt and clay were separated by sedimentation for a time calculated from Stokes' Law, and the clay fraction was retrieved by siphoning. The recovered clay fraction was dried, and characterised by powder X-ray diffraction on a Shimadzu XRD 6000 diffractometer. The X-ray diffraction pattern was recorded with $\mathrm{Cu} \mathrm{K} \alpha$ radiation, over the angular range $3-45^{\circ}$ (20). The X-ray tube was operated at a current of $30 \mathrm{~mA}$, and a potential of $30 \mathrm{kV}$; the angular scan rate was $0.5^{\circ} \theta \mathrm{min}^{-1}$.

Granulometry. Clay and silt contents were determined by the hydrometer method, and sand content by the sieving method (Gee and Or 2002).

\section{Structural stability}

Soil structural stability was evaluated by means of three physical attributes: (i) clay readily dispersible in water (RDC); (ii) clay mechanically dispersible in water (MDC); and (iii) aggregate stability, assessed through the stability of the water percolation (WP) in soil columns. The reasons for the choice of these parameters and the methodologies adopted for their determination were based upon studies developed and detailed in Dexter et al. (2011), and Auerswald (1995; WP).

Readily dispersible clay in water (RDC). The RDC was quantified by measuring the turbidity of a suspension of the soil in water. First, $5 \mathrm{~g}$ of soil, with moisture matching soil conditions at the time of the field collection (Table 1) was placed in a $150-\mathrm{mL}$ flask. Next, $125 \mathrm{~mL}$ of deionised water was added and the flask was then manually inverted four times and allowed to stand so that particles with diameters larger than clay settled to the bottom of the flask by sedimentation. After $16 \mathrm{~h}, 30 \mathrm{~mL}$ of suspension was withdrawn from the centre of the flask, without disturbance of the sediment at the base, and transferred to a turbidimeter (Hach Turbidimeter 2100AN) to measure turbidity of the suspension in NTU (nephelometric turbidity units). In parallel, the water content of the soil sample was determined, and used to calculate the mass of dry soil $(m(\mathrm{ds}))$ in the $5 \mathrm{~g}$ aliquot of soil taken for the RDC quantification. The measured turbidity was normalised to a concentration of dry soil of $1 \mathrm{~g} \mathrm{~L}^{-1}$ :

$$
\left[\mathrm{RDC} / \mathrm{NTU}\left(\mathrm{g} \mathrm{L}^{-1}\right)^{-1}\right]=\frac{[\text { turbidity } / \mathrm{NTU}]}{1000 \times\left(\frac{[m(\mathrm{ds}) / \mathrm{g}]}{125}\right)}
$$

Triplicate determinations of the RDC were performed for each of the 40 soil samples collected from each site (Layer 1 and Layer 2 from the 10 trenches established in NT cultivated part of the site and Layer 1 and Layer 2 from the 10 uncultivated reference points.).
Mechanically dispersible clay in water (MDC). Quantification of the MDC was also based upon turbidity measurements. Once the $30 \mathrm{~mL}$ sample of the suspension required for the quantification of the RDC had been withdrawn from the flask, $30 \mathrm{~mL}$ of deionised water were added to the flask, making the volume $125 \mathrm{~mL}$. The flask was then turned over continuously about a horizontal axis at $100 \mathrm{rpm}$ for $3 \mathrm{~h}$ to promote mechanical dispersion of the clay. The flask was then left to stand undisturbed on a bench for $16 \mathrm{~h}$, so that particles with diameters larger than those of clay settled to the bottom by sedimentation. Upon completion, $30 \mathrm{~mL}$ of suspension was withdrawn from the centre of the flask, ensuring that the sediment at the base of the flask was not disturbed, transferred to the turbidimeter, and the turbidity of the suspension was recorded in NTU. As for the RDC, the measured turbidity was normalised to a concentration of dry soil in the flask of $1 \mathrm{~g} \mathrm{~L}^{-1}$, so that the MDC was expressed in NTU/ $\left(\mathrm{g} \mathrm{L}^{-1}\right.$; Eqn 1). All soil samples were analysed in triplicate.

Stability of WP. Soil columns were prepared inside cylindrical glass tubes with an internal diameter of $15 \mathrm{~mm}$ and a height of $105 \mathrm{~mm}$. The lower end of the tube was covered with a piece of nylon fabric, and medium sand (diameter 0.25 to $0.50 \mathrm{~mm}$ ) was added to a height of $2 \mathrm{~mm}$ to avoid any obstruction to the departure of water from the tube. Subsequently, $10 \mathrm{~g}$ of air-dried aggregates, with particle diameters between 1 and $2 \mathrm{~mm}$ was added. A further $2 \mathrm{~mm}$ layer of medium sand was created above the column of aggregates to prevent aggregate rupture through direct contact with water. The aggregates within the tube were mechanically homogenised by dropping the tube vertically 10 times from a height of $2 \mathrm{~cm}$ onto a rigid surface. Deionised water was then allowed to percolate through the column of aggregates under a constant hydrostatic pressure of $20 \mathrm{hPa}$ for $600 \mathrm{~s}$. The volume of water that percolated through the column during this time is referred to as the percolation stability and provides a measure of the stability of the soil aggregates. The methodology described above has been used and validated in previous studies on soil structural stability (e.g. Auerswald 1995; Mbagwu and Auerswald 1999; Guedes Filho et al. 2013).

\section{Statistical analysis}

Mean values for the various indicators of soil structural stability were compared between the 12 groups, defined by system of management (NT or not cultivated), layer (1 or 2), and site (LV-BR, LV-PF or LV-PG), by examining their respective confidence intervals $(P<0.15$; Payton et al. 2000). An exploration of the relationships between variables considered to be indicators of structural stability and the other measured soil attributes was conducted through assessments of bivariate scatter plots for each layer. The strength of the relationships between structural stability indicators and chemical variables was evaluated through the canonical correlations, supported by F-tests $(\alpha=0.05)$ following recommendations by Manly (2005). Once the most important variables within each group had been identified, linear regressions with multiple variables were performed to parametrise the stability variables as linear combinations of chemical variables. All analyses were conducted within the $\mathrm{R}$ statistical computation environment (R Core Team 2015). 


\section{Results}

\section{Chemical, physical and mineralogical properties}

Soil textural analysis revealed differences among the three sites (Table 2), with soil from site LV-BR showing the lowest clay content and the highest sand content, whereas the soil from LVPG had the highest clay and the lowest sand contents. The soil from LV-PF was found to have intermediate contents of clay and sand.

The cultivated soils has higher concentrations of nutrients, lower acidity, and lower concentrations of $\mathrm{Al}^{3+}$ than the noncultivated soils. These differences were larger in the surface layer $(0-0.05 \mathrm{~m})$ than in the second layer $(0.10-0.15 \mathrm{~m})$. The cultivated soil from LV-PF presented the highest concentrations of nutrients, the highest $\mathrm{pH}$ in water, and the lowest concentration of $\mathrm{Al}^{3+}$, with the differences from the $\mathrm{LV}$ PG soil being the most pronounced. The highest content of OC was found in the non-cultivated soils, independent of depth. However, for the surface layer at LV-PG, the levels of OC quantified in the cultivated soil were similar to those in the noncultivated soil.

Soil from LV-BR presented the lowest contents of $\mathrm{SiO}_{2}$ (96-112 $\left.\mathrm{g} \mathrm{kg}^{-1}\right)$ and $\mathrm{Al}_{2} \mathrm{O}_{3}\left(100-121 \mathrm{~g} \mathrm{~kg}^{-1}\right)$. The highest concentrations of $\mathrm{SiO}_{2}\left(158-213 \mathrm{~g} \mathrm{~kg}^{-1}\right)$ were found in the LVPF soil, which had intermediate levels of $\mathrm{Al}_{2} \mathrm{O}_{3}$ (122 to $178 \mathrm{~g}$ $\mathrm{kg}^{-1}$ ), whereas the LV-PG soil had the highest concentrations of $\mathrm{Al}_{2} \mathrm{O}_{3}\left(223\right.$ to $\left.280 \mathrm{~g} \mathrm{~kg}^{-1}\right)$ and intermediate concentrations of $\mathrm{SiO}_{2}$ (124-139 $\left.\mathrm{g} \mathrm{kg}^{-1}\right)$. The $\mathrm{Fe}_{2} \mathrm{O}_{3}$ concentrations ranged from 73 to $126 \mathrm{~g} \mathrm{~kg}^{-1}$. The highest values for the indices $K_{i}(1.89-2.20)$ and $K_{r}(1.37-1.62)$ were observed in the samples collected from LV$\mathrm{PF}$, and the lowest in the LV-PG soil samples $\left(K_{i}: 0.77-0.97 ; K_{r}\right.$ : $0.67-0.78)$. The qualitative mineralogical analyses of the clay fraction by powder X-ray diffraction (Fig. 2) indicated the presence of kaolinite, hematite, and quartz in the soil samples collected from all three of the sites, which is normal for these Oxisols (Ker 1997). Gibbsite was only detected in the LV-PF and LV-PG soils, its peak being more pronounced for the LV-PG soil. Taking into consideration the values of the indices $K_{i}$ and $K_{r}$ with the qualitative mineralogical analyses, it is inferred that the LV-PG soil is the most weathered with higher level of gibbsite, whereas soils from LV-PF and LV-BR are less weathered and richer in kaolinite (Ker 1997).

\section{Structural stability indicators of the soil \\ Readily dispersible clay (RDC)}

Confidence intervals of the mean RDC values show that, irrespective of the layer from which the soil was collected, the soils cultivated under NT had higher levels of RDC than the non-cultivated soils (Fig. 3). The only case in which the cultivated to non-cultivated difference was not significant was for Layer 1 soil from LV-PF. In the subsurface soil (Layer 2), the quantity of RDC in the cultivated soil was approximately four times greater than in the non-cultivated soil from the same site (Fig. 3). Examining the non-cultivated soils, for each site there was no difference in RDC values for the two sampled layers. However, for the cultivated soils, RDC in the subsurface layer was greater than in the surface layer (Fig. 3). There was a clear difference between the cultivated and non-cultivated soils from the three sites, with the largest concentrations of RDC being invariably found in the cultivated soils, principally in the subsurface layer.

\section{Mechanically dispersible clay in water (MDC)}

The concentration of MDC in the soil samples collected from the cultivated areas was significantly greater than in the noncultivated soils (Fig. 4). The sole exception was the subsurface layer for site LV-PG. Differences in the MDC levels between the layers were only significant for soil taken from the cultivated areas, for which greater quantities of MDC were observed in the subsurface layer. For the cultivated soils, those from LV-PG and LV PF presented the lowest and the highest quantities of MDC (Fig. 4).

\section{Water percolation (WP)}

The WP was observed to be faster through the non-cultivated soils than through the cultivated soils (Fig. 5). Differences in WP values between the layers and the sites were not significant. The rate of WP through the soil was inversely correlated with the contents of RDC and MDC (Fig. 6).

\section{Relationships between structural stability indicators and other soil attributes}

Exploratory analyses conducted by examining bivariate scatter plots between a variable selected from the set of three structural stability indicators (RDC, MDC, and WP) and a variable selected from the set of soil physical and chemical attributes (Table 2) permitted a global visualisation of the relationships between soil structure stability and the other soil attributes. Separate scatter plots constructed from the data points provided by the characterisation of the soil in the surface layer $(0-0.05 \mathrm{~m}$, Layer 1$)$ and the subsurface layer $(0.10-0.15 \mathrm{~m}$, Layer 2$)$ revealed the extent to which indicator variables of soil structural stability were related to the measured and calculated chemical variables of the soil in the two layers. This led to the selection of $\mathrm{pH}, \mathrm{K}^{+}$, $\mathrm{Ca}^{2+}, \mathrm{Mg}^{2+}, \mathrm{Al}^{3+}, \% \mathrm{Al}, \mathrm{OC}$, and $\mathrm{Fe}_{2} \mathrm{O}_{3}$ as potential explanatory variables for the three indicators of soil structural stability (RDC, $\mathrm{MDC}$, and WP). Canonical correlation analysis was then utilised to identify and measure the relationships between the indicator variables (Group I) and the explanatory variables (Group II):

$$
\left[\begin{array}{c}
\text { Group I } \\
\text { Structural stability } \\
\text { indicators } \\
\mathrm{RDC}+\mathrm{MDC}+\mathrm{WP}
\end{array}\right] \text { vs }\left[\begin{array}{c}
\text { Group II } \\
\mathrm{pH}+\mathrm{K}^{+}+\mathrm{Ca}^{2+}+\mathrm{Mg}^{2+}+\mathrm{Al}^{3+} \\
+\% \mathrm{Al}+\mathrm{OC}+\mathrm{Fe}_{2} \mathrm{O}_{3}
\end{array}\right]
$$

Results of the separate canonical correlation analyses for the two soil layers (Table 3) demonstrated a strong correlation between Group I (soil structural stability) and Group II (soil chemical attributes). For the surface layer, the first two canonical pairs were associated with canonical correlations of 0.99 and 0.87 between Group I and Group II respectively, explaining 94 and $4 \%$ of the total covariance respectively. In the case of the subsurface layer, the canonical correlations for the first two canonical pairs were 0.99 and 0.94 for Group I and Group II respectively, explaining 82 and $16 \%$ of the total covariance 


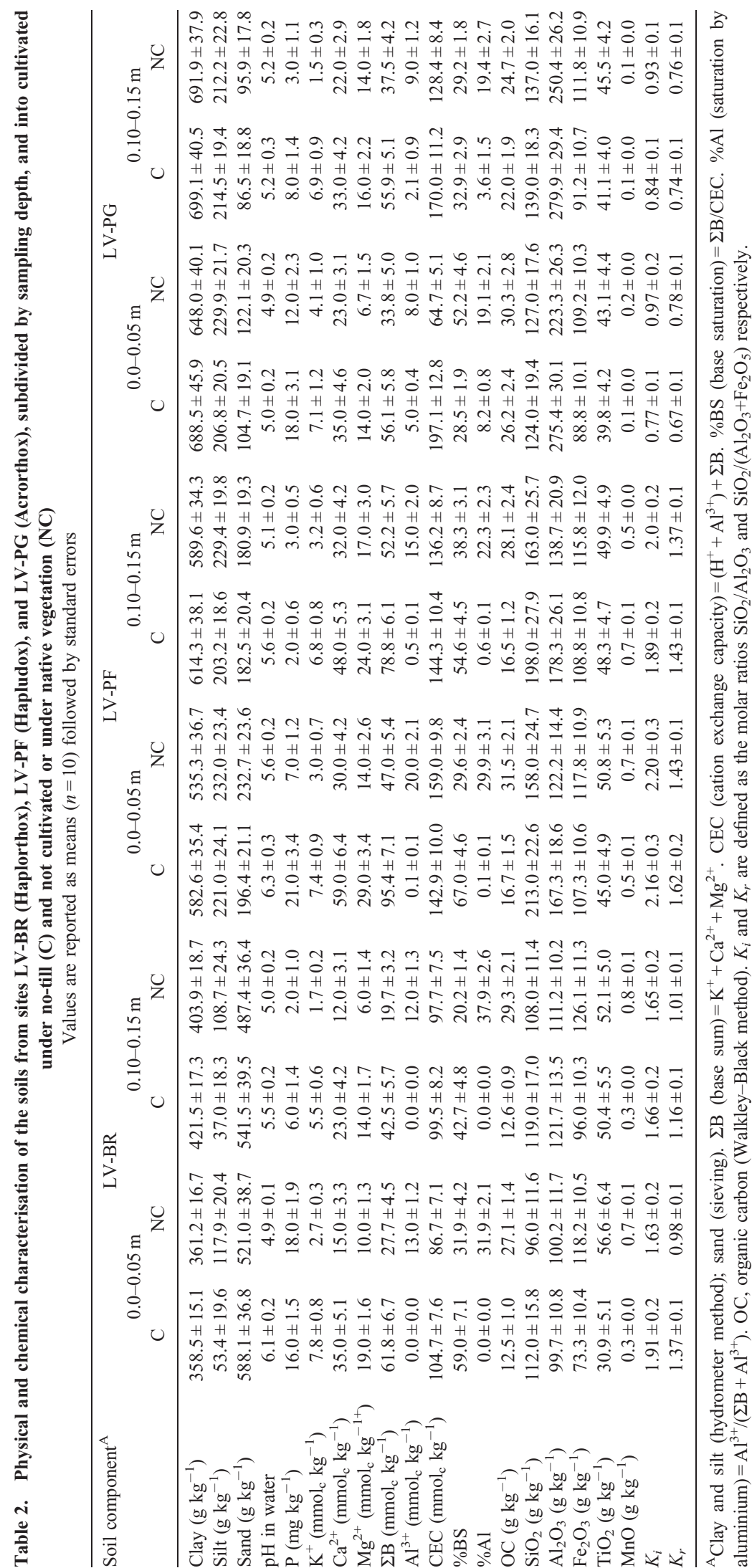


between the groups respectively. For both layers, the third canonical pair was not found to be significant. Since only the first two canonical pairs were significant for both layers, and together they were sufficient to explain $98 \%$ of the total covariance between the groups, the subsequent evaluations were limited to the first two canonical pairs.

The canonical coefficients of the variables within the first two canonical pairs estimated by applying a maximisation of covariance model (canonical weights) are presented in Table 4. The values of the canonical coefficients for the variables of Group II permit the identification of the chemical attributes that are most important in relating linear combinations of the Group I variables that generate the canonical variables of

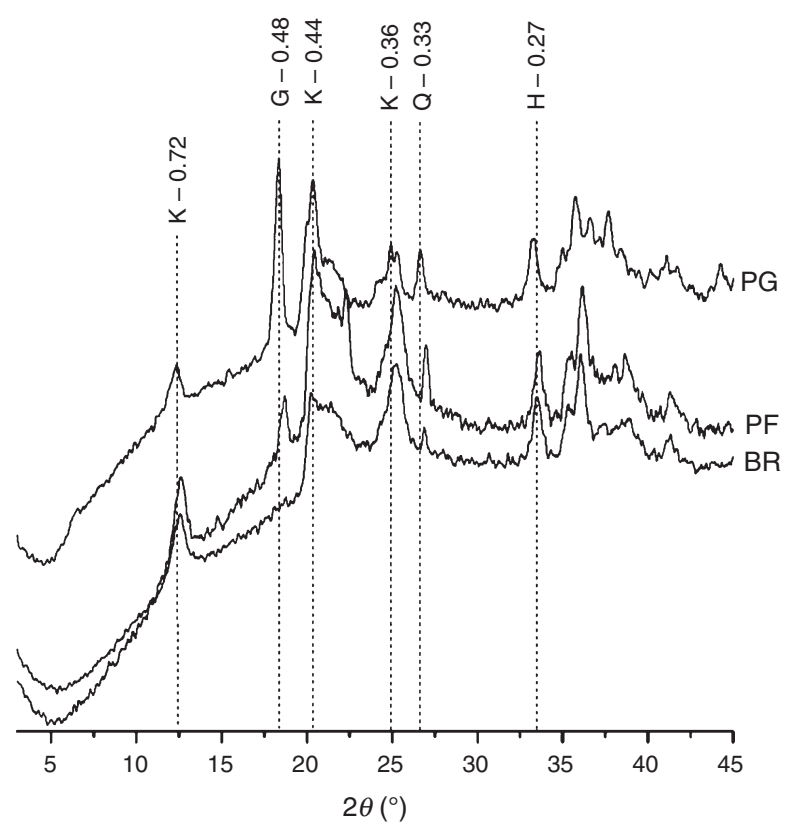

Fig. 2. Powder X-ray diffraction patterns of the clay fraction isolated from soil samples collected from the $0-0.20 \mathrm{~m}$ layer in a non-cultivated area of each of the three sites. BR: Haplorthox from Bom Recreio (RS); PF: Hapludox from Passo Fundo (RS); and PG: Acrorthox from Ponta Grossa (PR). The identified peaks are from the minerals kaolinite (K), gibbsite $(\mathrm{G})$, quartz $(\mathrm{Q})$, and hematite $(\mathrm{H})$. structural stability of the soil to the variables of Group II. In the case of the surface layer, the most important Group II variables were $\mathrm{pH}, \mathrm{K}^{+}, \mathrm{Al}^{3+}, \mathrm{OC}$, and $\mathrm{Fe}_{2} \mathrm{O}_{3}$, showing that the structural stability of the three studied Oxisols was principally influenced by the levels of these attributes. For the subsurface layer, $\mathrm{Ca}^{2+}$, $\mathrm{Al}^{3+}, \% \mathrm{Al}, \mathrm{OC}$, and $\mathrm{Fe}_{2} \mathrm{O}_{3}$ emerged as the most important Group II variables for the prediction of the Group I canonical variables. However, the weight for OC in the first canonical pair and for $\%$ $\mathrm{Al}$ in the second pair were much greater than for the other Group II variables. These results indicate that for the subsurface layer of Oxisols cultivated under NT the structural stability was influenced most strongly by the content of $\mathrm{OC}$ and the $\mathrm{Al}^{3+}$ saturation of the soil $(\% \mathrm{Al})$.

With the most important soil attributes for the prediction of the structural stability of the soil in the two layers identified, the next objective in the analysis was to establish the functional relationships between the three indicator variables and the soil attributes, obtained by stepwise multiple regression, with RDC, MDC, and WP treated as dependent variables. For the surface layer, the initial set of explanatory variables was $\mathrm{pH}, \mathrm{K}^{+}, \mathrm{OC}$, and $\mathrm{Fe}_{2} \mathrm{O}_{3} ; \mathrm{Al}^{3+}$ was excluded because of its very high correlation with soil $\mathrm{pH}$. For the subsurface layer, the initial set of explanatory variables was $\mathrm{Ca}^{2+}, \% \mathrm{Al}, \mathrm{OC}$, and $\mathrm{Fe}_{2} \mathrm{O}_{3}$; in this case, $\mathrm{Al}^{3+}$ was excluded because of its collinearity with \% Al. Finally, multiple regression was performed for the combined dataset from the two layers, with $\mathrm{pH}, \mathrm{K}_{+}, \mathrm{Ca}^{2+}, \% \mathrm{Al}, \mathrm{OC}$, and $\mathrm{Fe}_{2} \mathrm{O}_{3}$ as the initial set of explanatory variables.

Table 5 shows the linear equations with optimised parameter values obtained from model adjustment. With the exception of the equations for RDC and MDC for the surface layer, all included $\mathrm{OC}$ as a term, proving the influence of organic carbon on soil structural stability, independent of the layer under evaluation. In addition to $\mathrm{OC}$, the structural stability of the NT soil in the surface layer depends on the concentrations of $\mathrm{K}^{+}$ and $\mathrm{Fe}_{2} \mathrm{O}_{3}$, and $\mathrm{pH}$, whereas for the subsurface layer $\mathrm{Al}^{3+}$ saturation $(\% \mathrm{Al})$ is an additional important factor.

\section{Discussion}

Chemical factors in the structural stability of Oxisols managed under NT

The mineralogical composition of the Oxisols investigated in this study is predominantly kaolinite together with oxides

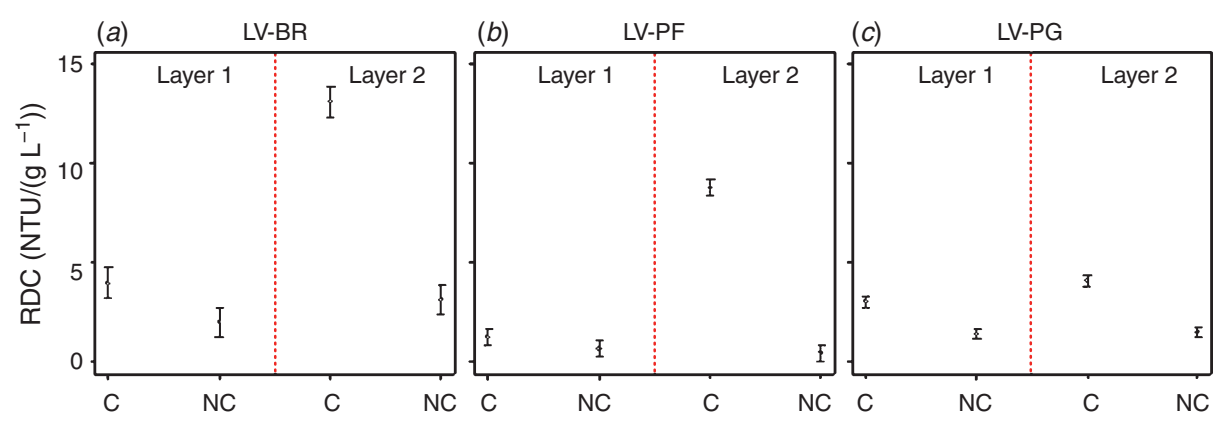

Fig. 3. Readily dispersible clay in water (RDC) for the soils collected from the three sites. (a) LV-BR: Haplorthox, (b) LV-PF: Hapludox; and (c) LV-PG: Acrorthox. Samples were collected from areas cultivated under no-till (C) and non-cultivated areas (NC). Layer 1: 0.0-0.05 m; Layer 2: 0.10-0.15 m. Vertical bars indicate the confidence intervals $(P<0.15)$ for the mean RDC values. 


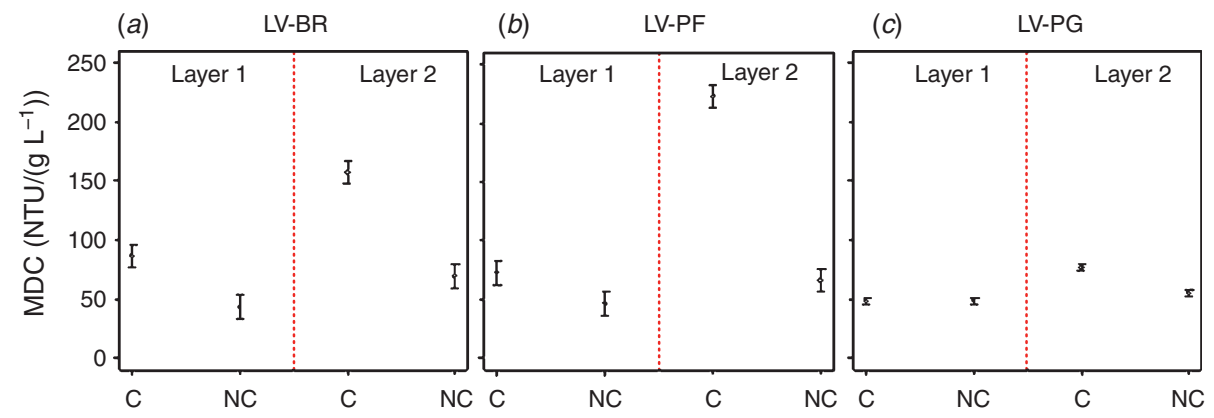

Fig. 4. Mechanically dispersible clay in water (MDC) for the soils collected from the three sites. (a) LV-BR: Haplorthox, (b) LV-PF: Hapludox; and (c) LV-PG: Acrorthox. Samples were collected from areas cultivated under no-till (C) and non-cultivated areas (NC). Layer 1: 0.0-0.05 m; Layer 2: 0.10-0.15 m. Vertical bars indicate the confidence intervals $(P<0.15)$ for the mean MDC values.

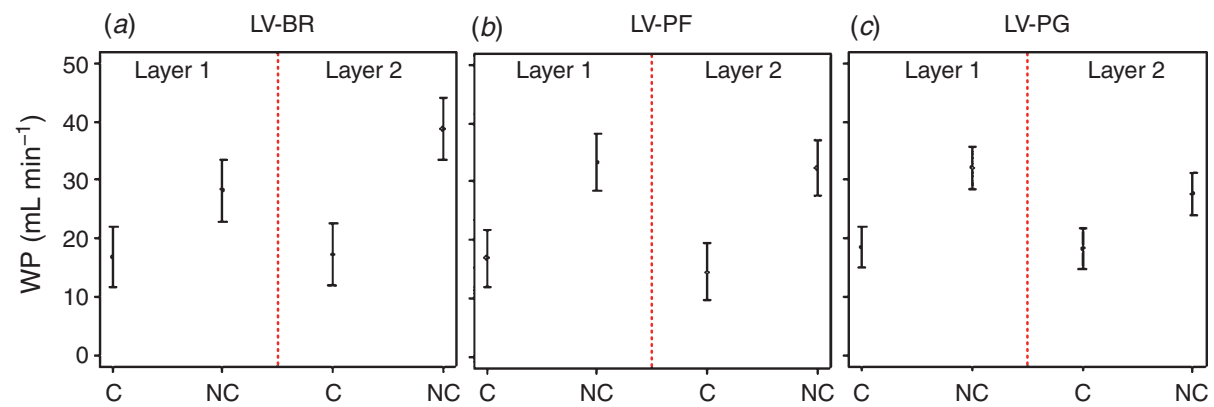

Fig. 5. Water percolation (WP) through the soils collected from the three sites. (a) LV-BR: Haplorthox, (b) LV-PF: Hapludox, and (c) LV-PG: Acrorthox. Samples were collected from areas cultivated under no-till (C) and non-cultivated areas (NC). Layer 1: 0-0.05 m; Layer 2: 0.10-0.15 m. Vertical bars indicate the confidence intervals $(P<0.15)$ for the mean WP values.
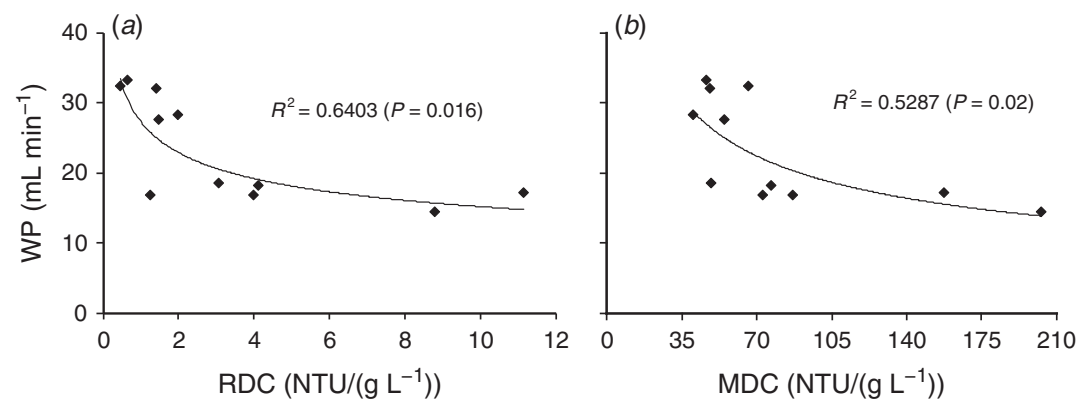

Fig. 6. Water percolation (WP) plotted as a function of $(a)$ the readily dispersible clay in water (RDC) and (b) the mechanically dispersible clay in water (MDC). Data points are from the complete group of sampled Red Latosols: all three sites, cultivated under no-till and non-cultivated (under native vegetation), in Layer $1(0-0.05 \mathrm{~m})$ and Layer $2(0.10-0.15 \mathrm{~m})$.

of Fe and $\mathrm{Al}$ (Fig. 2), which possess variable surface charge (Uehara and Gillman 1980). The greater structural stability of non-cultivated soils than NT-cultivated soils (Figs 3-5) may be viewed as a consequence of the physical and chemical equilibria at play in these soil systems. Of particular importance are the $\mathrm{OC}$ and $\mathrm{Al}^{3+}$ concentrations and the $\mathrm{pH}$ (Table 2); concentrations of $\mathrm{OC}$ and $\mathrm{Al}^{3+}$ were higher for the noncultivated soils, which also had a lower $\mathrm{pH}$. At a $\mathrm{pH}$ below the PZC of the oxides, the soil becomes electropositive, which makes it possible for the electronegative functional groups of soluble organic anions to bind to the electropositive domains of soil particles. The adsorption of the organic anions reduces the positive surface charges on the oxides (Coleman et al. 1989), allowing the oxides to link together through $\mathrm{Al}^{3+}$ bridges (Ramos and McBride 1996; Vrdoljak and Sposito 2002). Thus, the tendency of the soil particles to flocculate is increased by an increased concentration of organic matter and a greater abundance of $\mathrm{Al}^{3+}$ in the non-cultivated soils, coupled 
Table 3. Canonical correlation analysis between the variables of Group I (indicators of soil structural stability) and the variables of Groups II (selected explanatory chemical attributes of the soil)

\begin{tabular}{lcccc}
\hline $\begin{array}{l}\text { Canonical } \\
\text { pair }\end{array}$ & $\begin{array}{c}\text { Canonical } \\
\text { correlation }\end{array}$ & $\begin{array}{c}\text { Proportion of covariance } \\
\text { explained } \\
\text { by canonical } \\
\text { pair }\end{array}$ & $\begin{array}{c}\text { cumulative } \\
\text { sum }\end{array}$ \\
\hline \multicolumn{5}{c}{-value } \\
First & 0.99 & 0.94 & 0.94 & 0.0000 \\
Second & 0.87 & 0.04 & 0.98 & 0.0498 \\
Third & 0.76 & 0.02 & 1.00 & 0.1637 \\
& Layer & $2(0.10-0.15 m)$ & subsurface \\
First & 0.99 & 0.82 & 0.82 & 0.0000 \\
Second & 0.94 & 0.16 & 0.98 & 0.0051 \\
Third & 0.71 & 0.02 & 1.00 & 0.2628 \\
\hline
\end{tabular}

Table 4. Estimated canonical coefficients of the structural stability variables (Group I) and the selected soil chemical variables (Group II) in the first two canonical pairs, for the surface and subsurface layers RDC, readily dispersible clay; MDC, mechanically dispersible clay; WP, water percolation; OC, organic carbon

\begin{tabular}{|c|c|c|c|c|}
\hline \multirow[t]{2}{*}{ Variable } & \multicolumn{2}{|c|}{$\begin{array}{l}\text { Surface }(0-0.05 \mathrm{~m}) \\
\text { Canonical pair }\end{array}$} & \multicolumn{2}{|c|}{$\begin{array}{c}\text { Subsurface }(0.10-0.15 \mathrm{~m}) \\
\text { Canonical pair }\end{array}$} \\
\hline & First & Second & First & Second \\
\hline \multicolumn{5}{|l|}{ Group I } \\
\hline RDC & 0.211 & 1.171 & 0.358 & 0.575 \\
\hline MDC & 0.380 & 0.719 & 0.006 & 1.541 \\
\hline WP & -0.605 & -0.312 & -0.768 & -0.708 \\
\hline \multicolumn{5}{|l|}{ Group II } \\
\hline $\mathrm{pH}$ & 0.212 & 1.247 & 0.046 & -0.489 \\
\hline $\mathrm{K}^{+}$ & 0.204 & 0.886 & 0.078 & 0.206 \\
\hline $\mathrm{Ca}^{2+}$ & -0.240 & 0.139 & 0.611 & 0.621 \\
\hline $\mathrm{Mg}^{2+}$ & 0.236 & 0.494 & 0.569 & 0.194 \\
\hline $\mathrm{Al}^{3+}$ & -0.611 & 0.056 & -0.671 & -0.532 \\
\hline$\% \mathrm{Al}$ & 0.332 & 0.038 & -0.380 & 2.518 \\
\hline $\mathrm{OC}$ & -0.415 & -0.318 & -1.378 & 0.434 \\
\hline $\mathrm{Fe}_{2} \mathrm{O}_{3}$ & -0.418 & -1.163 & -0.287 & -1.432 \\
\hline
\end{tabular}

with the lower $\mathrm{pH}$ of the medium (Parks and Bruyn 1962; Ramos and McBride 1996), thereby increasing the stability of the aggregates in the soil from non-cultivated areas (Figs 3-5).

The reduction of Oxisols structural stability under NT, compared with the non-cultivated Oxisols, can result in environmental and agricultural problems. The waterdispersible clay is directly linked to the soil erosion (Castro and Logan 1991; Igwe 2005). Denardin et al. (2008) reported the erosion occurrence in Oxisols under NT in farms from South of Brazil and stressed that the soil erosion process promoted the loading of limestone, fertilisers and organic matter from the uppermost layer of these soils, resulting in both economic damage to the agricultural system and environmental pollution. The transport of fertilisers, soil particles, organic matter and water out of the crop field promotes pollution of surface water sources, reduction of the volume of water stored in the soil, and reduction of the recharge of groundwater aquifers (Schick et al. 2000; Dalla Costa 2004). In addition, waterdispersible clay can promote surface crusting and decreases soil permeability to water and gases (Bolan et al. 1996), influencing the capability of the soil to provide water and oxygen to plants.

The decrease in the structural stability of the Oxisols managed under NT (Figs 3-5) is in part due to the surface application of limestone and fertilisers, which consequently concentrate in the soil surface layer. The lower quantity and lesser quality of the organic matter added to the cultivated soil compared with the non-cultivated soil may also have contributed (Tivet et al. 2013; Sá et al. 2014). These factors lead to physicochemical alterations in the cultivated system (Haynes and Naidu 1998; Li and Zhang 2007) in both the surface layer (where fertilisers and ameliorants accumulate; Costa and Rosolem 2007; Nunes et al. 2014; Dang et al. 2015) and in the subsurface layer (where there is minimal addition of organic matter). In tropical and subtropical soils, the negative effects of limestone and fertiliser on saturated hydraulic conductivity, physical properties, water infiltration, and water erosion have previously been reported (Castro and Logan 1991; Roth and Pavan 1991; Fontes et al. 1995; Fontes et al. 2001; Soprano 2002; Spera et al. 2008). Comparison of an Oxisol under

Table 5. Results of multiple regression, with stepwise elimination of explanatory variables, to obtain linear expressions for the prediction of the three indicators of soil structural stability from the chemical attributes of the sampled Oxisols

RDC, readily dispersible clay; MDC, mechanically dispersible clay; WP, water percolation; NTU, nephelometric turbidity units; OC, organic carbon

\begin{tabular}{|c|c|c|c|}
\hline Equation & $R^{2}$ & $p$-value & Equation no. \\
\hline \multicolumn{4}{|l|}{ Surface layer $(0-0.05 \mathrm{~m})$} \\
\hline$\left[\mathrm{RDC} / \mathrm{NTU}\left(\mathrm{g} \mathrm{L}^{-1}\right)^{-1}\right]=5.748+0.571 \mathrm{pH}-0.661\left[\mathrm{Fe}_{2} \mathrm{O}_{3}\left(\mathrm{~g} \mathrm{~kg}^{-1}\right)\right]$ & 0.65 & 0.0009 & 2 \\
\hline$\left[\mathrm{MDC} / \mathrm{NTU}\left(\mathrm{g} \mathrm{L}^{-1}\right)^{-1}\right]=5.493+16.641 \mathrm{pH}-3.737\left[\mathrm{Fe}_{2} \mathrm{O}_{3}\left(\mathrm{~g} \mathrm{~kg}^{-1}\right)\right]$ & 0.67 & 0.0008 & 3 \\
\hline$\left[\mathrm{WP} / \mathrm{mL}(10 \mathrm{~min})^{-1}\right]=69.758-18.08\left[\mathrm{~K}^{+}\left(\mathrm{g} \mathrm{kg}^{-1}\right)\right]+1.582\left[\mathrm{OC}\left(\mathrm{g} \mathrm{kg}^{-1}\right)\right]+1.783\left[\mathrm{Fe}_{2} \mathrm{O}_{3}\left(\mathrm{~g} \mathrm{~kg}^{-1}\right)\right]$ & 0.60 & 0.0026 & 4 \\
\hline \multicolumn{4}{|l|}{ Subsurface layer $(0.10-0.15 \mathrm{~m})$} \\
\hline$\left[\mathrm{RDC} / \mathrm{NTU}\left(\mathrm{g} \mathrm{L}^{-1}\right)^{-1}\right]=25.411-0.107 \times \% \mathrm{Al}-0.831\left[\mathrm{OC}\left(\mathrm{g} \mathrm{kg}^{-1}\right)\right]$ & 0.70 & 0.0008 & 5 \\
\hline$\left[\mathrm{MDC} / \mathrm{NTU}\left(\mathrm{g} \mathrm{L}^{-1}\right)^{-1}\right]=254.000-0.331 \times \% \mathrm{Al}-6.431\left[\mathrm{OC}\left(\mathrm{g} \mathrm{kg}^{-1}\right)\right]$ & 0.51 & 0.0051 & 6 \\
\hline$\left[\mathrm{WP} / \mathrm{mL}(10 \mathrm{~min})^{-1}\right]=6.913-0.410 \times \% \mathrm{Al}-0.524\left[\mathrm{OC}\left(\mathrm{g} \mathrm{kg}^{-1}\right)\right]$ & 0.70 & 0.0001 & 7 \\
\hline \multicolumn{4}{|l|}{ Combined data from the two layers } \\
\hline$\left[\mathrm{RDC} / \mathrm{NTU}\left(\mathrm{g} \mathrm{L}^{-1}\right)^{-1}\right]=23.949+1.941 \mathrm{pH}-0.570\left[\mathrm{OC}\left(\mathrm{g} \mathrm{kg}^{-1}\right)\right]-1.711\left[\mathrm{Fe}_{2} \mathrm{O}_{3}\left(\mathrm{~g} \mathrm{~kg}^{-1}\right)\right]$ & 0.43 & 0.0005 & 8 \\
\hline$\left[\mathrm{MDC} / \mathrm{NTU}\left(\mathrm{g} \mathrm{L}^{-1}\right)^{-1}\right]=122.139+0.972 \times \% \mathrm{Al}-0.849\left[\mathrm{OC}\left(\mathrm{g} \mathrm{L}^{-1}\right)^{-1}\right]-0.763\left[\mathrm{Fe}_{2} \mathrm{O}_{3}\left(\mathrm{~g} \mathrm{~kg}^{-1}\right)\right]$ & 0.53 & 0.0004 & 9 \\
\hline$\left[\mathrm{WP} / \mathrm{mL}(10 \mathrm{~min})^{-1}\right]=9.129-0.401 \times \% \mathrm{Al}-0.411\left[\mathrm{OC}\left(\mathrm{g} \mathrm{kg}^{-1}\right)\right]$ & 0.51 & 0.0005 & 10 \\
\hline
\end{tabular}


cultivation with the same soil under forest cover revealed greater clay dispersion and lower aggregate stability, which were attributed to liming and a reduction in the level of OC in the cultivated soil (Roth and Pavan 1991; Castro and Logan 1991). The results obtained in this study confirm OC as one of the principal soil attributes that influences the structural stability of the soils. Also, identified as important for the surface layer were $\mathrm{pH}, \mathrm{K}^{+}, \mathrm{Al}^{3+}$, and $\mathrm{Fe}_{2} \mathrm{O}_{3}$ (Table 4; Table 5: Eqns 2-4), and the content of $\mathrm{Al}^{3+}$ in the subsurface layer (Table 4; Table 5: Eqns 5-7).

For soil particles in contact with solutions of electrolytes, the charge on the surface of the particles is altered by the $\mathrm{pH}$, the valence of the ions, and the concentration of electrolytes in the solution (Arora and Coleman 1979; Itami and Kyuma 1995; Ramos and McBride 1996). Limestone applied to Oxisols managed under NT, which is concentrated in the surface layer, raises the $\mathrm{pH}$ of the medium and increases the negative charge of soil particles. The presence of more cations of lower valence with a greater radius of hydration reduce the electrostatic forces between kaolinite and the oxides, increasing the content of dispersible clay in the soil (Figs 3 and 4) and decreasing the rate of WP (Fig. 5).

High correlations between the structural stability of Oxisols and their $\mathrm{Al}^{3+}$ content and $\mathrm{pH}$, such as those found in the present study, have previously been reported by Roth and Pavan (1991), Castro and Logan (1991), and Fontes et al. (1995). The pH is one of the principal factors affecting the dispersion of the particles in soils with a variable charge (Suarez et al. 1984; Bolan et al. 1996), which can be carried by percolating water and deposited in the subsurface layer, thereby obstructing the natural porosity of the soil (Haridasan and Chibber 1971). Due to the concentration of roots and crop residues close to the surface of the soil, the OC inputs into the subsurface layer is minimal for soils cultivated under NT (Nunes et al. 2015b), so that the eluviated clay remains dispersed.

The non-cultivated soil guarantees greater quantities of organic matter (Table 2) of superior quality (Leite et al. 2003). The conversion of native forest into farmland substantially diminishes the formation of organo-mineral complexes and the structural stability of the soil, in comparison to the non-cultivated soil (Dal Ferro et al. 2012; Tivet et al. 2013). Derpsch et al. (2014) have argued that the efficiency of NT agricultural production depends upon the presence of crop residues on the soil and can benefit from crop diversification. The positive effect of OC on the structural stability of the soil (Etana et al. 2009; Udom et al. 2016), seen in the surface and subsurface layers (Figs 3 and 4), serves to reinforce this view.

The greater structural stability of the soil managed under NT at site LV-PG in comparison to sites LV-BR and LV-PF (Figs 3-5) can be related to the higher levels of OC and $\mathrm{Fe}_{2} \mathrm{O}_{3}$ (Table 2), attributes which are known to influence the structural stability of a soil (Regelink et al. 2015). There were also mineralogical differences between the soils. Both the indices $K_{\mathrm{i}}$ and $\mathrm{Kr}$ (Table 2) were smaller for the LV-PG soils than for the soils from LV-BR and LV-PF. Furthermore, the qualitative mineralogical analysis (Fig. 2) revealed the presence of gibbsite in the LV-PG, and, possibly, a lower kaolinite concentration. The kaolinite is formed of two basal faces that are, in principle, electrically neutral. However, it is estimated that this mineral presents $\sim 10 \%$ of its total surface covered by external faces and broken edges, where reactive $\mathrm{OH}$ groups are found. Since the kaolinite PZC ( 4) is much lower than the gibbsite PZC ( 9; Essington 2004), an increase in the $\mathrm{pH}$ of Oxisols under NT has supported surface deprotonation of surface edges of kaolinite, increasing the liquid negative electric charge of soil (Tan 1998; Alkan et al. 2005). Considering the electrostatic potential increase, attraction forces between kaolinite and both $\mathrm{Fe}$ and $\mathrm{Al}$ oxides were reduced as the repulsion forces between colloids enhanced (Ramos and McBride 1996). As a result, colloidal suspension stability decreased (Tan 1998), influencing the soil structural stability. The PZC of the studied soil was not quantified, and further research is important to improve our knowledge of the physicochemical properties of these soils under different agricultural practices. Nonetheless, the results from the present research and the data from previously studies suggest that kaolinitic Oxisols are more susceptible to soil chemical degradation than gibbsite Oxisols.

Moreover, the higher levels of OC in the NT-managed soil from LV-PG is a reflection of greater diversification in the species cultivated (Martins et al. 2012), both in summer and winter, and the maintenance of plant cover throughout the year. In the LV-BR and LV-BR farms, in the winter season, the land is left fallow and occasionally cultivated with wheat; and in the LV-PG, besides corn and soybean, the crop rotation system includes a wide range of green manures species (Crotalaria breviflora, Crotalaria juncea, Cajanus cajan, Mucuna deeringiana and Pennisetum glaucum, in the summer, and wheat, black oats, rye and vetch, in the winter). This diversification of species can improve OC stocks (Blanco-Canqui et al. 2017) and the microbial biomass in soils (Babujia et al. 2010), thus improving the structural stability of Oxisols (Tivet et al. 2013). In contrast, at sites LV-BR and LV-PF the production model is predominantly soybean monoculture in the summer and a fallow period in the winter, which has led to reduced levels of OC (Table 2) and greater soil dispersion in the subsurface layer (Figs 3 and 4), as reported by Etana et al. (2009). This in turn increases the vulnerability of the soil to structural degradation in subsequent seasons (Watts and Dexter 1997).

\section{Current chemical management of soils cultivated under NT and soil conservation}

We determined that the NT farming systems can still be improved to ensure that this technique of the soil and crop management is further aligned with conservation objectives. Productivity and conservation diverge when optimisation of the former is founded upon current models of soil fertility that are expressed exclusively in terms of chemical indicators and neglect the biological and physical aspects of soil fertility. Without tillage, the conditioning of the soil for plant development becomes a function of the soil structure created by the biota and the delivery of fertilisers, which enter though the soil surface (Nunes et al. 2014). The soil layer in which the crops are raised develops physical differences from other layers (Reichert et al. 2009; Nunes et al. 2015a; Dang et al. 2015) and becomes chemically distinct (Costa and Rosolem 2007; Nunes et al. 2014). Under these conditions, the traditional 
models for the evaluation of soil fertility, which are built on the assumption of soil homogeneity, cease to be sufficient.

In contrast to conventional management systems, in NT, storage and availability of water, storage and diffusion of heat, oxygen flow, permeability to air, and resistance to root penetration are soil properties that are inextricably linked to soil fertility (Denardin and Denardin 2015). Since soil structure determines these processes, it must be considered alongside biological and chemical factors in the evaluation of fertility (Magdoff and van Es 2009; Iqbal et al. 2014). Additionally, soil sampling requires examination as our results have demonstrated vertical heterogeneity in the chemical and physical properties of Oxisols cultivated under NT (Denardin and Denardin 2015), and recommendations for lime and fertilisers based on conventional sampling may be upwardly biased. Excess nutrients may then accumulate at or close to the surface of the soil (Costa and Rosolem 2007; Nunes et al. 2014; Dang et al. 2015), aggravate physical and chemical stratification (Table 2; Figs 3-5), compromise structural stability (Figs 3-5), and create problems with erosion (Derpsch et al. 2014).

To improve chemical management in NT, we must change the way we sample soils to evaluate their fertility. First, before soil sampling in areas under NT for at least 5 years, verify whether physical and chemical stratification has occurred within the $0-0.2 \mathrm{~m}$ layer of soil. It is important to avoid mixing stratified layers from the collected soil samples into a heterogenous sample. Chemical fertility analysis from heterogeneous samples that were originally stratified by sufficient or insufficient fertility levels will result in inaccurate or non-existent data. The second step is to consider that a compacted layer may interfere with hydrologic dynamics, plantwater and nutrient availability, air and heat diffusion, and plant and root development from both resistance to penetration and in the soil reaction solution itself. Therefore, the soil fertility under NT must be interpreted based on the soil biological characteristics, which can indicate an agronomically desirable soil to promote nutrient use efficiency. If soil stratification is found in the $0-0.2 \mathrm{~m}$ layer there are management practices to address the issue such as chiseling and use of seeders equipped with fixed shanks in deeper action to the inferior limit of the compact layer. This kind of seeder can break the compact soil layer and, at the same time, promote the chemical soil fertility in profundity depositing fertilisers into the soil subsurface layer, which can stimulate root development of the plants at this layer (Nunes et al. 2014, 2015a). To prevent an increase in clay dispersal at the soil surface and to minimise the increase of soil bulk density in the subsurface layer, it is necessary to reduce lime application in the soil surface and to diversify the production systems through crop rotations to produce high amount of biomass, increase organic carbon storage and maintain soil stability (Conceição et al. 2013; Tivet et al. 2013; Derpsch et al. 2014; Corbeels et al. 2016; Miranda et al. 2016).

\section{Conclusion}

Oxisols under NT were investigated and showed a reduction in stability, greater clay dispersion and slower percolation of water than equivalent non-cultivated soil. These negative effects were traced to a reduction in the supply of organic material to the soil and inappropriate chemical management underpinned by erroneous soil fertility diagnostics, without considering structural and biological attributes and the vertical heterogeneity in the chemical and physical properties of soils under NT to recommend lime and fertilisers. For the surface layer of these soils, the principal explanatory variables for alterations in stability were changes in the $\mathrm{pH}$ of the soil, and the content of $\mathrm{K}^{+}, \mathrm{Al}^{3+}$, and $\mathrm{OC}$, whereas for the subsurface layer the most important variables were the levels of $\mathrm{Al}^{3+}$ and OC in the soil.

\section{Acknowledgements}

Thanks to the São Paulo Research Foundation (FAPESP, Brazil - Process number 2015/12934-3) and to the Brazilian Research Council (CNPq Process number 382783/2014-0) for the scholarships and funding. We also wish to express thanks to the Brazilian Agricultural Research Corporation (Embrapa) for field support.

\section{References}

Alkan M, Demirbas Ö, Doğan M (2005) Electrokinetic properties of kaolinite in mono and multivalent electrolyte solutions. Microporous and Mesoporous Materials 83, 51-59. doi:10.1016/j.micromeso.2005. 03.011

Arora HS, Coleman NT (1979) The influence of electrolyte concentration on flocculation of clay suspensions. Soil Science 127, 134-139. doi:10.1097/00010694-197903000-0000

Auerswald K (1995) Percolation stability of aggregates from arable topsoil. Soil Science 159, 142-148. doi:10.1097/00010694-199502000-00009

Babujia LC, Hungria M, Franchini JC, Brookes PC (2010) Microbial biomass and activity at various soil depths in a Brazilian Oxisol after two decades of no-tillage and conventional tillage. Soil Biology \& Biochemistry 42, 2174-2181. doi:10.1016/j.soilbio.2010.08.013

Blanco-Canqui H, Francis CA, Galusha TD (2017) Does organic farming accumulate carbon in deeper soil profiles in the long term? Geoderma 288, 213-221. doi:10.1016/j.geoderma.2016.10.031

Bolan NS, Syers JK, Sumner ME (1996) Origin of the effect of $\mathrm{pH}$ on the saturated hydraulic conductivity of soils. Communications in Soil Science and Plant Analysis 27, 2265-2278. doi:10.1080/001036296093 69702

Castro C, Logan TJ (1991) Liming effects on the stability and erodibility of some Brazilian Oxisols. Soil Science Society of America Journal 55, 1407-1413. doi:10.2136/sssaj1991.03615995005500050034x

Chaplain V, Défossez P, Delarue G, Roger-Estrade J, Dexter AR, Richard G, Tessier D (2011) Impact of lime and mineral fertilizers on mechanical strength for various soil pHs. Geoderma 167-168, 360-368. doi:10.10 16/j.geoderma.2011.08.003

Coleman DC, Oades JM, Uehara G (1989) 'Dynamics of soil organic matter in tropical ecosystems.' (University of Hawaii: Honolulu)

Conceição PC, Dieckow J, Bayer C (2013) Combined role of no-tillage and cropping systems in soil carbon stocks and stabilization. Soil \& Tillage Research 129, 40-47. doi:10.1016/j.still.2013.01.006

Corbeels M, Marchão RL, Siqueira Neto M, Ferreira EG, Madari EB, Scopel E, Brito OR (2016) Evidence of limited carbon sequestration in soils under no-tillage systems in the Cerrado of Brazil. Scientific Reports 6, 21450. doi:10.1038/srep21450

Costa A, Rosolem CA (2007) Liming in the transition to no-till under a wheat-soybean rotation. Soil \& Tillage Research 97, 207-217. doi:10. 1016/j.still.2007.09.014

Dal Ferro N, Berti A, Francioso O, Ferrari E, Matthews GP, Morari F (2012) Investigating the effects of wettability and pore size distribution on aggregate stability: the role of soil organic matter and the humic fraction. 
European Journal of Soil Science 63, 152-164. doi:10.1111/j.13652389.2012.01427.x

Dalla Costa R 2004. Nutrients in runoff water under no-till system with vertical mulching. MSc Thesis, University of Santa Maria, Santa Maria, Brazil.

Dang YP, Moody PW, Bell MJ, Seymour NP, Dalal RC, Freebairn DM, Walker SR (2015) Strategic tillage in no-till farming systems in Australia's northern grains-growing regions: II. Implications for agronomy, soil and environment. Soil \& Tillage Research 152, 115-123. doi:10.1016/j.still. 2014.12.013

Denardin JE, Denardin ND (2015) Facts and myths in soil science: physic, management and conservation of soil. Newsletter of the Brazilian Soil Science Society 40, 18-21.

Denardin JE, Kochhann RA, Faganello A, Sattler A, Manhago DD (2008) Vertical mulching as a soil conservation practice to manage runoff in no tillage systems. Brazilian Journal of Soil Science 32, 2847-2852.

Denardin JE, Kochhann RA, Faganello A (2011) April 15 national day of soil conservation: the agriculture developed in Brazil conservationist or not? Newsletter of the Brazilian Soil Science Society 36, 10-15.

Derpsch R, Franzluebbers AJ, Duiker SW, Reicosky DC, Koeller K, Friedrich T, Sturny WG, Sá JCM, Weiss K (2014) Why do we need to standardize no-tillage research? Soil \& Tillage Research 137, 16-22. doi:10.1016/j.still.2013.10.002

Dexter AR, Richard G, Czyż EA, Davy J, Hardy M, Duval O (2011) Clay dispersion from soil as a function of antecedent water potential. Soil Science Society of America Journal 75, 444-455. doi:10.2136/sssaj2010. 0088

Donagema, GK, Campos, DVB, Calderano, SB, Teixeira, WG, Viana, JHM, (2011) 'Manual of soil method analysis.' 2nd edn. (Embrapa Solos: Rio de Janeiro)

Essington ME (2004) 'Soil water chemistry: an integrative approach.' (CRC Press: Boca Raton, FL)

Etana A, Rydberg T, Arvidsson J (2009) Readily dispersible clay and particle transport in five Swedish soils under long-term shallow tillage and mouldboard ploughing. Soil \& Tillage Research 106, 79-84. doi:10. 1016/j.still.2009.09.016

Fontes MPF, Gjorup GB, Alvarenga RC, Nascif PGS (1995) Calcium salts and mechanical stress effects on water-dispersible clay of Oxisols. Soil Science Society of America Journal 59, 224-227. doi:10.2136/sssaj 1995.03615995005900010034x

Fontes MPF, Camargo AO, Sposito G (2001) Electrochemistry of colloidal particles and its relationship with the mineralogy of highly weathered soils. Scientia Agrícola 58, 627-646. doi:10.1590/S0103-90162001000 300029

Food and Agriculture Organization of the United Nations (FAO) (2016) AQUASTAT database. Available at http://www.fao.org/nr/water/aquas tat/data/query/results.html [verified 15 June 2017].

Gee GW, Or D (2002) Particle size analysis. In 'Methods of soil analysis'. (Eds JH Dane, GC Topp) pp. 255-293. (Soil Science Society of America: Madison, WI)

Guedes Filho O, Silva AP, Giarola NFB, Tormena CA (2013) Structural properties of the soil seedbed submitted to mechanical and biological chiseling under no-tillage. Geoderma 204-205, 94-101. doi:10.1016/ j.geoderma.2013.04.017

Haridasan M, Chibber RK (1971) Effect physical and chemical properties on the erodibility of some soils of the Malwa Plateau. Journal of the Indian Society of Soil Science 19, 293-298.

Haynes RJ, Naidu R (1998) Influence of lime, fertilizer and manure applications on soil organic matter content and soil physical conditions: a review. Nutrient Cycling in Agroecosystems 51, 123-137. doi:10.1023/ A: 1009738307837

Hudson N (1977) 'Soil conservation.' 2nd edn. (Cornel University Press: New York)
Igwe CA (2005) Erodibility in relation to water-dispersible clay for some soils of eastern Nigeria. Land Degradation \& Development 16, 87-96. doi:10.1002/ldr.647

Iqbal M, van Es HM, Hassan A, Schindelbeck RR, Moebius-Clune BN (2014) Soil health indicators as affected by long-term application of farm manure and cropping patterns under semi-arid climates. International Journal of Agriculture and Biology 16, 2.

Itami K, Kyuma K (1995) Dispersion behavior of soil from reclaimed lands with poor physical properties and their characteristics with special reference to clay mineralogy. Soil Science and Plant Nutrition 41, 45-54. doi:10.1080/00380768.1995.10419557

Ker JC (1997) Latossolos do Brasil: uma revisão. Geonomos 5, 17-40. doi:10.18285/geonomos.v5i1.187

Leite LFC, Mendonça ES, Neves JCL, Machado PLOA, Galvão JCC (2003) Total stocks of organic carbon and its pools in Acrisols under forest and under maize cultivated with mineral and organic fertilization. Brazilian Journal of Soil Science 27, 821-832.

Li JT, Zhang B (2007) Paddy soil stability and mechanical properties as affected by long-term application of chemical fertilizer and animal manure in subtropical China. Pedosphere 17, 568-579. doi:10.1016/S10 02-0160(07)60067-8

Madari B, Machado POA, Tores E, Andradea AG, Valencia LIO (2005) No tillage and crop rotation effects on soil aggregation and organic carbon in a Rhodic Ferralsol from southern Brazil. Soil \& Tillage Research 80, 185-200. doi:10.1016/j.still.2004.03.006

Magdoff FR, van Es HM (2009) 'Building soils for better crops: sustainable soil management.' Handbook Series Book 10. (Sustainable Agriculture Research and Education: Waldorf, MD)

Manly BJF (2005) 'Multivariate statistical methods: a primer.' 3rd edn. (Chapman \& Hall, CRC, Taylor \& Francis Group)

Martins MR, Angers DA, Corá JE (2012) Carbohydrate composition and water-stable aggregation of an Oxisol as affected by crop sequence under no-till. Soil Science Society of America Journal 76, 475-484. doi:10. 2136/sssaj2011.0110

Mbagwu JSC, Auerswald K (1999) Relationship of percolation stability of soil aggregates to land use, selected properties, structural indices and simulated rainfall erosion. Soil \& Tillage Research 50, 197-206. doi:10.1016/S0167-1987(99)00006-9

Mehra OP, Jackson ML (1960) Iron oxide removal from soils and clays by a dithionite-citrate system buffered with sodium bicarbonate. Clays and Clay Minerals 3, 317-327.

Miranda E, Carmo J, Couto E, Camargo P (2016) Long-term changes in soil carbon stocks in the Brazilian Cerrado under commercial soybean. Land Degradation \& Development 27, 1586-1594. doi:10.1002/ldr.2473

Nunes MR, Denardin JE, Faganello A, Pauletto EA, Pinto LFS (2014) Effect of seed drill with fixed shanks for deep action in soil under no-till. Brazilian Journal of Soil Science 38, 627-638.

Nunes MR, Denardin JE, Pauletto EA, Faganello A, Pinto LFS (2015a) Mitigation of clayey soil compaction managed under no-tillage. Soil \& Tillage Research 148, 119-126. doi:10.1016/j.still.2014.12.007

Nunes MR, Denardin JE, Pauletto EA, Faganello A, Pinto LFS (2015b) Effect of soil chiseling on soil structure and root growth for a clayey soil under no-tillage. Geoderma 259-260, 149-155. doi:10.1016/j.geoder ma.2015.06.003

Parks GA, Bruyn PL (1962) The zero point of charge of oxides. Journal of Physical Chemistry 66, 967-973. doi:10.1021/j100812a002

Payton ME, Miller AE, Raun WR (2000) Testing statistical hypotheses using standard error bars and confidence intervals. Communications in Soil Science and Plant Analysis 31, 547-551. doi:10.1080/0010362000 9370458

R Core Team (2015) 'R: a language and environment for statistical computing.' (R Foundation for Statistical Computing: Vienna, Austria). Available at http://www.R-project.org/. 
Ramos ACH, McBride MB (1996) Goethite dispersibility in solutions of variable ionic strength and soluble organic matter content. Clays and Clay Minerals 44, 286-296. doi:10.1346/CCMN.1996.0440213

Regelink IC, Stoof CR, Rousseva S, Wenga L, Lair GJ, Kram P, Nikolaidis N, Kercheva M, Banwart S, Comans RNJ (2015) Linkages between aggregate formation, porosity and soil chemical properties. Geoderma 247-248, 24-37. doi:10.1016/j.geoderma.2015.01.022

Reichert JM, Suzuki LEAS, Reinert DJ, Horn R, Hakansson I (2009) Reference bulk density and critical degree-of-compactness for no-till crop production in subtropical highly weathered soils. Soil \& Tillage Research 102, 242-254. doi:10.1016/j.still.2008.07.002

Roth CH, Pavan MA (1991) Effects of lime and gypsum on clay dispersion and infiltration in samples of a Brazilian Oxisol. Geoderma 48, 351-361. doi:10.1016/0016-7061(91)90053-V

Sá JCM, Tivet F, Lal R, Briedis C, Hartman DC, Santos JZ, Santos JB (2014) Long-term tillage systems impacts on soil $\mathrm{C}$ dynamics, soil resilience and agronomic productivity of a Brazilian Oxisol. Soil \& Tillage Research 136, 38-50. doi:10.1016/j.still.2013.09.010

Santos HG, Jacomine PKT, Anjos LH, Oliveira VA, Oliveira JB, Coelho MR, Lumbreras JF, Cunha TJF (2006) 'Brazilian system of soils classification.' 3rd edn. (Embrapa Solos: Rio de Janeiro)

Schick J, Bertol I, Batistela O (2000) Soil erosion of a clayey Inceptisol under different crop and tillage systems: ii. Nutrient and organic carbon losses. Brazilian Journal of Soil Science 24, 437-447.

Siqueira Neto M, Scopel E, Corbeels M, Cardoso AC, Douzet J, Fellere C, Piccolo MC, Cerri C, Bernoux M (2010) Soil carbon stocks under notillage mulch-based cropping systems in the Brazilian Cerrado: an onfarm synchronic assessment. Soil \& Tillage Research 110, 187-195. doi:10.1016/j.still.2010.07.010

Six J, Feller C, Denef K, Ogle SM, Sá JCM, Albrechi A (2002) Soil organic matter, biota and aggregation in temperate and tropical soils - effects of no-tillage. Agronomie 22, 755-775. doi:10.1051/agro:2002043

Soane BD, Ball BC, Arvidsson J, Basch G, Moreno F, Roger-Estrade J (2012) No-till in northern, western and southwestern Europe: a review of problems and opportunities for crop production and the environment. Soil \& Tillage Research 118, 66-87. doi:10.1016/j.still.2011.10.015
Soprano E (2002) Stability of aggregates and clay dispersion as function of liming. MSc Thesis, Federal University of Rio Grande do Sul, Porto Alegre, Brazil.

Spera ST, Denardin JE, Escosteguy PAV, Santos HP, Figueroa EA (2008) Clay dispersion in microaggregates of soil incubated with limestone. Brazilian Journal of Soil Science 32, 2613-2620.

Sposito G (2008) 'The chemistry of soils.' (Oxford University Press: New York)

Suarez DL, Rhoades JD, Lavado R, Grieve CM (1984) Effect of pH on saturated hydraulic conductivity and soil dispersion. Soil Science Society of America Journal 48, 50-55. doi:10.2136/sssaj1984.0361599 $5004800010009 \mathrm{x}$

Tan KH (1998) 'Principles of soil chemistry.' 3rd edn. (Marcel Dekker: New York)

Tivet F, Sá JCM, Lal R, Briedis C, Borszowskei PR, Santos JB, Farias A, Eurich G, Hartman DC, Nadolny M, Bouzinac S, Séguy L (2013) Aggregate C depletion by plowing and its restoration by diverse biomass-C inputs under no-till in sub-tropical and tropical regions of Brazil. Soil \& Tillage Research 126, 203-218. doi:10.1016/j.still.2012.09.004

Udom BE, Nuga BO, Adesodun JK (2016) Water-stable aggregates and aggregate associated organic carbon and nitrogen after three annual applications of poultry manure and spent mushroom wastes. Applied Soil Ecology 101, 5-10. doi:10.1016/j.apsoil.2016.01.007

Uehara G, Gillman GP (1980) Charge characteristics of soils with variable and permanent charge minerals: I Theory. Soil Science Society of America Journal 44, 250-252. doi:10.2136/sssaj1980.0361599500440 $0020008 x$

United States Department of Agriculture (USDA) (2012) 'Soil taxonomy.' (USDA-NRCS: Washington, DC)

Vrdoljak G, Sposito G (2002) Soil aggregation hierarchy in a Brazilian oxisol. In 'Development of soil science'. (Eds A Violante, PM Huang, J-M Bollag, L Gianfreda) pp. 197-217. (Elsevier Science)

Watts CW, Dexter AR (1997) The influence of organic matter in reducing the destabilization of soil by simulated tillage. Soil \& Tillage Research 42, 253-275. doi:10.1016/S0167-1987(97)00009-3 